\title{
Dynamics of soil erosion rates and controlling factors in the Northern Ethiopian Highlands - towards a sediment budget
}

\author{
Jan Nyssen, ${ }^{1,2,3}$ Jean Poesen, ${ }^{2}$ Jan Moeyersons, ${ }^{4}$ Mitiku Haile ${ }^{3}$ and Jozef Deckers' \\ Division Soil and Water Management, K.U. Leuven, Leuven, Belgium \\ 2 Physical and Regional Geography Research Group, K.U. Leuven, Leuven, Belgium \\ ${ }^{3}$ Department of Land Resource Management and Environmental Protection, Mekelle University, Mekelle, Ethiopia \\ ${ }^{4}$ Royal Museum for Central Africa, Tervuren, Belgium
}

* Correspondence to: J. Nyssen, Division Soil and Water Management, K.U. Leuven, B-300I Leuven, Belgium. E-mail: Jan.nyssen@agr.kuleuven.ac.be

Received 28 December 2005: Revised I 4 May 2007; Accepted 30 May 2007

\begin{abstract}
This paper analyses the factors that control rates and extent of soil erosion processes in the 199 ha May Zegzeg catchment near Hagere Selam in the Tigray Highlands (Northern Ethiopia). This catchment, characterized by high elevations (2100-2650 m a.s.l.) and a subhorizontal structural relief, is typical for the Northern Ethiopian Highlands. Soil loss rates due to various erosion processes, as well as sediment yield rates and rates of sediment deposition within the catchment (essentially induced by recent soil conservation activities), were measured using a range of geomorphological methods. The area-weighted average rate of soil erosion by water in the catchment, measured over four years (1998-2001), is $14 \cdot 8 \mathbf{~ h a}^{-1} \mathbf{y}^{-1}$, which accounts for $98 \%$ of the change in potential energy of the landscape. Considering these soil loss rates by water, $28 \%$ is due to gully erosion. Other geomorphic processes, such as tillage erosion and rock fragment displacement by gravity and livestock trampling, are also important, either within certain land units, or for their impact on agricultural productivity. Estimated mean sediment deposition rate within the catchment equals $9 \cdot 2 \mathbf{t h a}^{-1} \mathbf{y}^{-1}$. Calculated sediment yield $\left(5 \cdot 6 \mathrm{t} \mathrm{ha}^{-1} \mathrm{y}^{-1}\right)$ is similar to sediment yield measured in nearby catchments. Seventy-four percent of total soil loss by sheet and rill erosion is trapped in exclosures and behind stone bunds. The anthropogenic factor is dominant in controlling present-day erosion processes in the Northern Ethiopian Highlands. Human activities have led to an overall increase in erosion process intensities, but, through targeted interventions, rural society is now well on the way to control and reverse the degradation processes, as can be demonstrated through the sediment budget. Copyright (c) 2007 John Wiley \& Sons, Ltd.
\end{abstract}

Keywords: sediment budget; sediment yield; soil and water conservation; Tigray; soil erosion rates; natural and anthropogenic causes of erosion; land resilience

\section{Introduction}

The magnitude of soil erosion processes in the Ethiopian Highlands finds its cause in the combination of erosive rains, steep slopes due to a rapid tectonic uplift during the Pliocene and Pleistocene and human impacts through deforestation, an agricultural system where the openfield with free stubble grazing dominates, impoverishment of the farmers and stagnation of agricultural techniques (Ståhl, 1974, 1990; Nyssen et al., 2004a, 2005). Over the last decades, active soil and water conservation (SWC) interventions have taken place, especially in the Northern Tigray Highlands (Nyssen et al., 2007b). An overall approach to assess the effectiveness of biological and physical conservation measures at catchment level would be the establishment of sediment budgets.

Sediment budgets have been used to determine the contribution of major stream basins to ocean sedimentation (Wilkinson, 2005; Syvitski and Milliman, 2007), or to estimate sub-basins' contributions to sediment load in these streams. For instance, in the Nile basin, as compared to the White Nile, the Blue Nile and Atbara drain the Ethiopian 


\section{J. Nyssen et al.}

Highlands and have the most important contribution to Aswan dam sedimentation (Sutcliffe and Parks, 1999; Garzanti et al., 2006). At the other end of the range of spatial scales, Luk et al. (1993) used a sediment budget to analyse sediment transport in a rill system in Southern Arizona (USA).

In a review paper on sediment budgets, Slaymaker (2003) points to the various applications such as the estimation of sediment yield, the importance of basin storage, the importance of dissolved components, the link to nutrient budgets and management implications.

Often sediment budget studies include detailed monitoring of one or two components of the budget (e.g. flood plain aggradation and reservoir sedimentation - Trimble, 1983; suspended sediment concentration for runoff from various land cover types - Cammeraat, 2004) and estimates of the remaining components using model applications for instance.

Sediment budgets have however rarely been established for the Ethiopian Highlands. Hurni (1985) reported, for a 116 ha catchment in Wollo (Northern Ethiopia), that the rate of sediment accumulation $\left(17 \mathrm{tha}^{-1} \mathrm{y}^{-1}\right)$ is more important than the rate of sediment export through the drainage system $\left(7 \mathrm{tha}^{-1} \mathrm{y}^{-1}\right)$. In a vegetation-rich catchment in South-Western Ethiopia, he found sediment accumulation rates of $30 \mathrm{t} \mathrm{ha}^{-1} \mathrm{y}^{-1}$ and sediment export rates through the river only $1.1 \mathrm{t} \mathrm{ha}^{-1} \mathrm{y}^{-1}$. Here, most of the sediment deposition occurs in densely vegetated areas along riverbanks. Based on rates reported in the literature, Nyssen et al. (2004a) present indicative sediment budgets for average Ethiopian catchments. These budgets are scale dependent: with catchment area increasing from $100 \mathrm{~km}^{2}$ to $10000 \mathrm{~km}^{2}$; the ratio between the mass of sediment deposited within the catchment and mass of total sediment export increases from approximately $3 / 1$ to more than $13 / 1$.

This paper reviews the different factors that control rates and extent of soil erosion processes in a representative catchment of the Northern Ethiopian Highlands. A synthesis is made of the results from previous studies focussing on the various processes in and around this catchment, including sheet and rill erosion (Nyssen et al., 2001, 2007c), gully erosion (Nyssen et al., 2002b, 2004b, 2006c), rock fragment movement over the surface (Nyssen et al., 2006b), tillage erosion (Nyssen et al., 2000b) and landsliding (Nyssen et al., 2002a). Effectiveness of soil erosion control measures (Descheemaeker et al., 2006; Desta et al., 2005) will also be taken into account.

Considering the approach in which the various process are studied, taking into account the land units present in the catchment, few comprehensive studies with measurements of process rates per land unit can be found, since the pioneering study by Trimble (1983). Though soil conservation undertakings such as stone bund building and the establishment of vegetation strips are well known for trapping sediment in transit (Lacey, 2000; Abu-Zreig, 2001; Desta et al., 2005), we could not trace any sediment budget that incorporates SWC measures. This may lead to overestimations of catchment sediment yields (Rey, 2003).

Therefore, the objectives of this paper are (1) to analyse the evolution of geomorphic process rates at different timescales, (2) to differentiate between natural and anthropogenic causes and (3) to elaborate a sediment budget for a representative catchment, incorporating the sediment sinks created by SWC activities.

\section{Methodology}

\section{Study area}

The May Zegzeg catchment (199.1 ha) near the town of Hagere Selam $\left(13^{\circ} 40^{\prime} \mathrm{N}, 39^{\circ} 10^{\prime} \mathrm{E}\right)$, located ca. $50 \mathrm{~km}$ WNW of Mekelle (Figure 1), was selected for this study as it is characterized by high elevations (2100-2650 m a.s.1.) and a subhorizontal structural relief, typical for the Northern Ethiopian Highlands. Furthermore, SWC measures, especially stone bund building and the establishment of exclosures (vegetation restoration), were implemented as part of routine land management activities that were started a decade before this study was carried out.

The Atbara-Tekeze river system drains the runoff from the study area to the Nile.

The main rainy season ( $>80 \%$ of total rainfall) extends from June to September but is preceded by three months of dispersed and less intense rains. Average yearly precipitation is $774 \mathrm{~mm}$; Figure 2 shows that the study years 19982001 had close to average rainfall. Field measurements also show that precipitation is highest near cliffs and other steep slopes, perpendicular to the main valleys, which are preferred flow paths for the air masses. High rain erosivity is due to large drop size (Nyssen et al., 2005).

The local geology comprises subhorizontal series of alternating hard and soft Antalo limestone layers, some $400 \mathrm{~m}$ thick, overlain by Amba Aradam sandstone (Hutchinson and Engels, 1970) (Figure 3). These Mesozoic sedimentary rocks are covered by two series of Tertiary lava flows, separated by silicified lacustrine deposits (Merla, 1938; Arkin et al., 1971; Merla et al., 1979).

Erosion, in response to the Miocene and Plio-Pleistocene tectonic uplifts (ca. $2500 \mathrm{~m}$ ), resulted in the formation of tabular, stepped landforms, reflecting the subhorizontal geological structure. The uppermost levels of the landscape at 
Northern Ethiopian Highland soil erosion rate dynamics and controlling factors

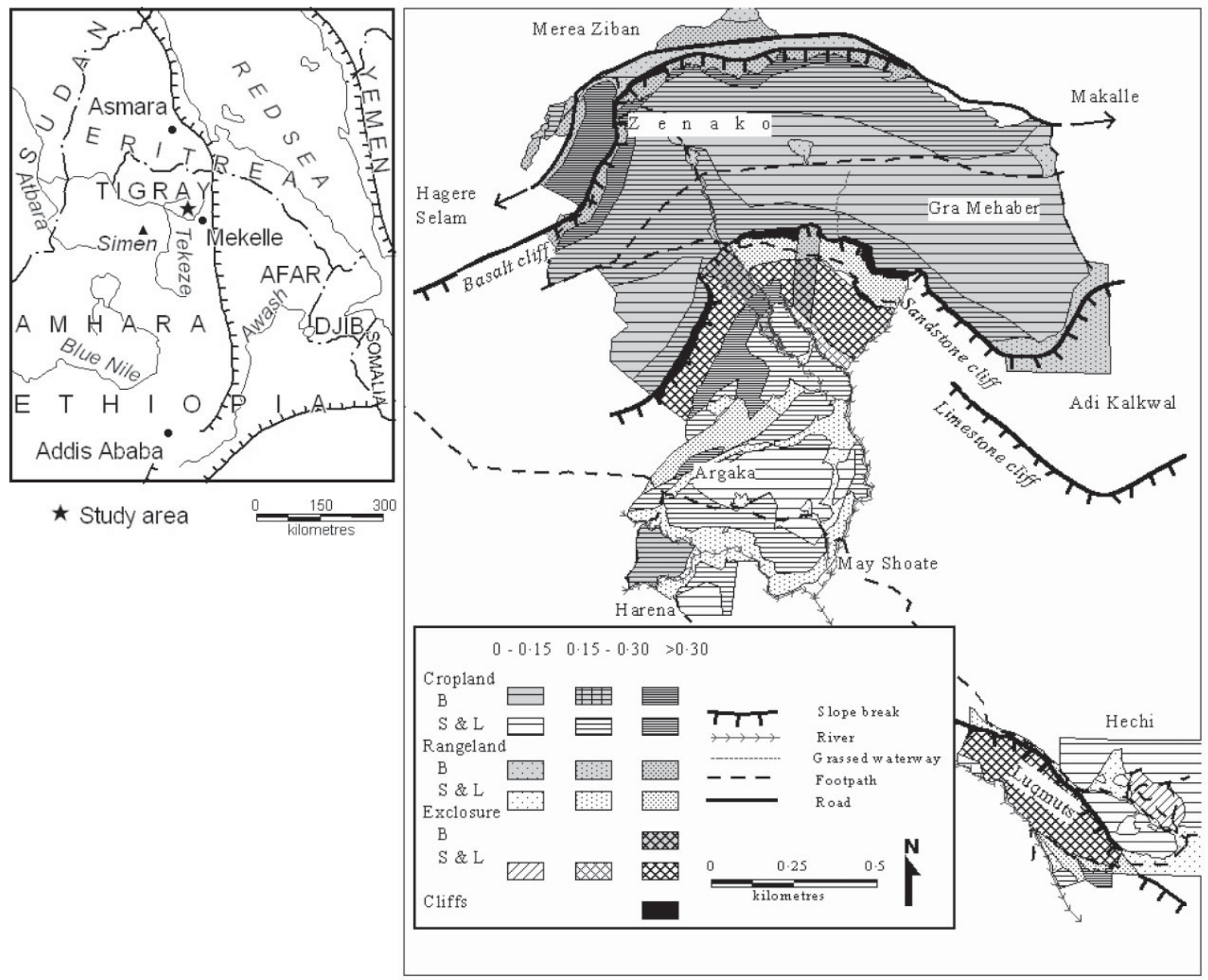

Figure I. Land units of the selected catchment, based on land use in 200I, lithology ( $\mathrm{B}=$ basalt; $\mathrm{S}=$ sandstone; $\mathrm{L}=$ limestone) and slope gradient (in $\mathrm{m} \mathrm{m}^{-1}$ ).

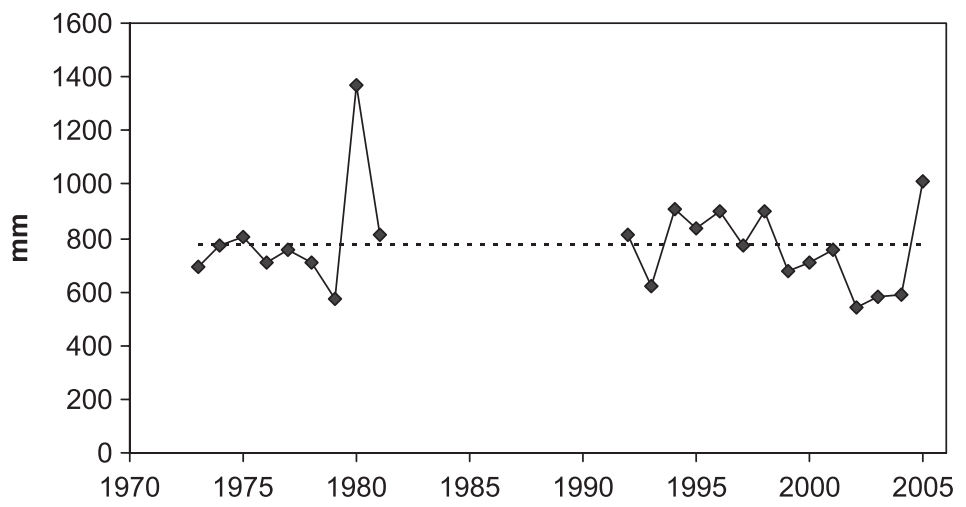

Figure 2. Yearly precipitation in Hagere Selam. Yearly average is 774 ( \pm II7) mm. Missing data correspond to the period of civil war and the years thereafter. Source, National Meteorological Services Agency, except 1992-1994, Dogu'a Tembien Agricultural Office. 


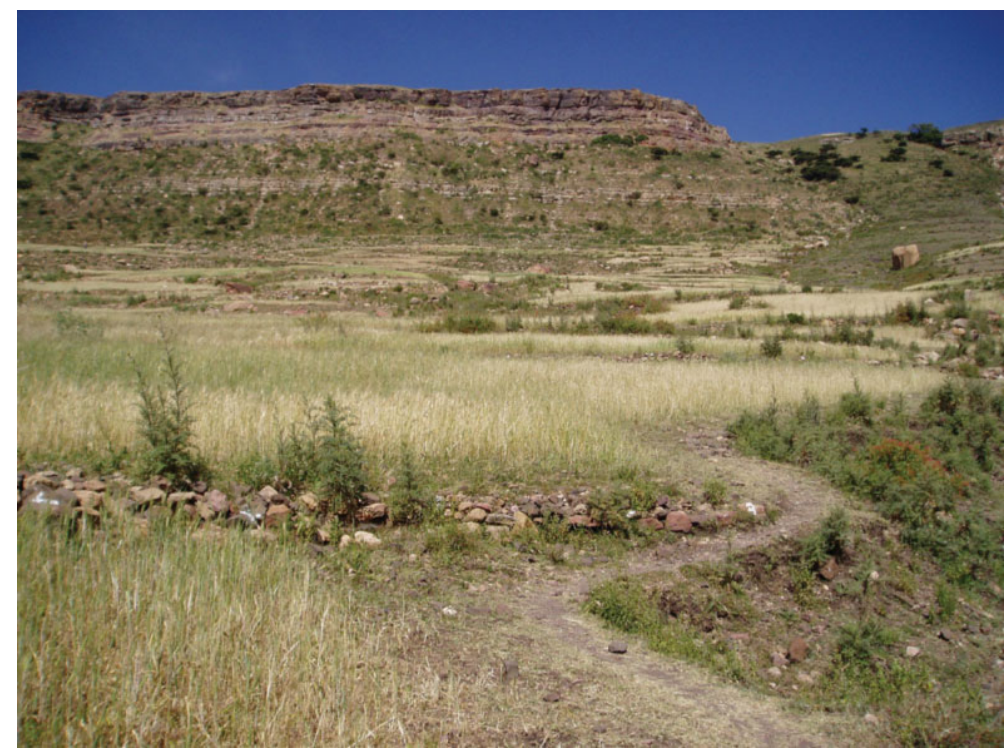

Figure 3. View from May Shoate (see Figure I) to the NNW in 2003 (photo, A.Van Damme). In front cropland with a stone bund in poor condition; at the back the Amba Aradam sandstone cliff with regenerating vegetation in an exclosure. Height difference equals around $200 \mathrm{~m}$. This figure is available in colour online at www.interscience.wiley.com/journal/espl

about 2700-2800 m a.s.l. are formed in the basalt series. Other structural levels correspond to the top of the Amba Aradam sandstone and to the top of hard layers within the Antalo limestone (Nyssen et al., 2002a).

Permanently cropped fields are the dominant land use, around $65 \%$, in the study area. The agricultural system in the Northern Ethiopian Highlands has been characterized as a 'grain-plough complex' (Westphal, 1975). The main crops are barley (Hordeum vulgare L.), wheat (Triticum sp.) and tef (Eragrostis tef), an endemic cereal crop. Various species of pulses are also an important part of the crop rotation. Soil tillage is carried out with ox-drawn ard ploughs (Nyssen et al., 2000b; Solomon et al., 2006). Livestock (cattle, sheep, and goats) are a major component of the agricultural system and graze freely. Steep slopes $\left(>0.3 \mathrm{~m} \mathrm{~m}^{-1}\right)$ are mainly under rangeland, parts of which have been set aside recently to allow vegetation recovery (exclosures) (Descheemaeker et al., 2006). After harvesting, stubble grazing is widespread.

\section{Measurement and analysis of sediment redistribution rates and processes}

Sheet and rill erosion (Figure 4) rates and processes were analysed through measurements on closed and open runoff plots during the period 1999-2001 (Nyssen et al., 2007c) and measurements of soil volumes deposited behind soil conservation structures (Desta et al., 2005).

Gully erosion was analysed by the AGERTIM (Assessment of Gully Erosion Rates Through Interviews and Monitoring) method involving measurements and monitoring of gully volumes and detailed interviews on their evolution (Nyssen et al., 2006c), and by use of thresholds for gully initiation, involving slope gradient and drainage area at the position of the gully head (Nyssen et al., 2002b).

The measurement of tillage erosion rates involved tracer experiments (Nyssen et al., 2000b) and measurement of volumes of soil removed from the foot of stone bunds (Desta et al., 2005).

Rates of creep movement were obtained through three years monitoring by theodolite (1999-2001) of distances between rock outcrops and boulders embedded in the colluvium of a re-activated landslide, considered to trace the average soil movement at the surface (Nyssen et al., 2002a). The assessment of rock fragment movement at the soil surface involved four years monitoring (1998-2001) of rockfall and two years monitoring of individual rock fragment movement along steep slope sections (Nyssen et al., 2006b).

The impact of the major soil conservation techniques on soil erosion and sediment deposition has also been measured. The effectiveness of stone bunds was assessed through comparison of volumes of soil accumulated behind stone bunds over a period of 3-21 years with predicted mean volumes of soil lost from the plot (Desta et al., 2005), as well as through measurements on runoff plots (Nyssen, 2001). Regrowing vegetation in exclosures traps large amounts of sediment transported within the catchment: thickness and areal extent of recently deposited sediment (over a period of 1-20 years) were measured (Descheemaeker et al., 2006). 


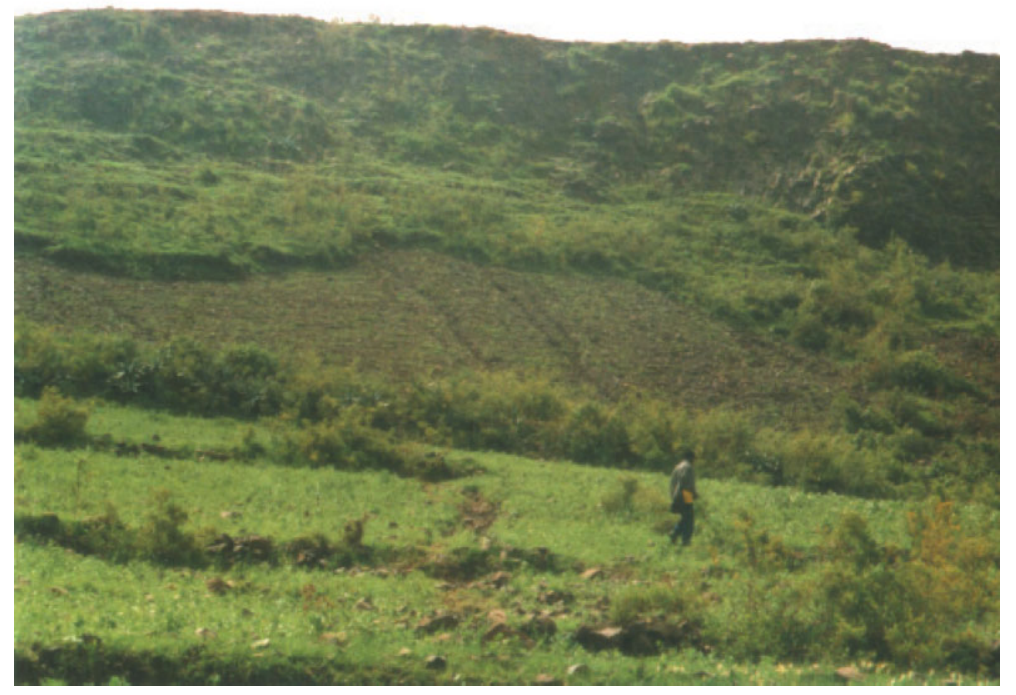

Figure 4. Rill erosion in steep cropland in 2000 (photo, J. Naudts). The view is from Zenako (see Figure I) to the north. Some small stone bunds are visible in the arable land in front and rangeland on the steep slope at the back. This figure is available in colour online at www.interscience.wiley.com/journal/espl

\section{Results}

\section{Sheet and rill erosion}

The average measured soil loss by sheet and rill erosion for 14 plot-years (Nyssen et al., 2007c) on arable land is $9.9( \pm 13.2) \mathrm{tha}^{-1} \mathrm{y}^{-1}$, which is well below the Ethiopian average obtained from the Soil Conservation Research Programme (SCRP) plots by Hurni (1990), i.e. $42 \mathrm{t} \mathrm{ha}^{-1} \mathrm{y}^{-1}$. Our runoff plots (5-6 m wide and 14-37 $\mathrm{m}$ long) were similar in size to the SCRP plots $(6 \mathrm{~m} \times 30 \mathrm{~m}$; Herweg and Ludi, 1999). The difference in soil loss rates is most probably related to a high surface rock fragment cover (Nyssen et al., 2001), to an extensive implementation of stone bunds (Desta et al., 2005) and to less rain and smaller total rain intensity (Nyssen et al., 2005) in Tigray compared with the Central Ethiopian Highlands. Soil types are also different: Regosols and Cambisols are dominant in Tigray whereas Vertisols, Luvisols, Nitisols and Chromic Cambisols dominate in Central Ethiopia. Furthermore, Hurni's estimates are based on data collected during the degradational phase of the drought-prone early 1980s. On rangeland in the study area, mean $\left(n=7\right.$ plot-years) soil loss $\left(17 \cdot 4 \mathrm{tha}^{-1} \mathrm{y}^{-1}\right)$ is relatively high, which is probably due to large runoff coefficients from overgrazed areas, and the fact that most rangeland is located on steep slopes. In forests and exclosures, a mean ( $n=14$ plot-years) soil loss of $3 \cdot 5 \mathrm{t} \mathrm{ha}^{-1} \mathrm{y}^{-1}$ was measured (Nyssen et al., 2007c).

\section{Gully erosion}

Independently computed, area-specific long-term rates of soil loss by gully erosion in various catchments of the study area have a similar order of magnitude, i.e. between 2.3 and $7.4 \mathrm{t} \mathrm{ha}^{-1} \mathrm{y}^{-1}$ (Nyssen et al., 2006c). At present, average area-specific short-term gully erosion rates are $1 \cdot 1 \mathrm{tha}^{-1} \mathrm{y}^{-1}$.

Monitoring of gully erosion rates in the study area during three years revealed an increase of gully volume from 22805 to $23877 \mathrm{~m}^{3}$, corresponding to a specific gully erosion rate of $4 \cdot 1 \mathrm{t} \mathrm{ha}^{-1} \mathrm{y}^{-1}$ (Nyssen et al., 2006c).

\section{Tillage erosion}

Soil translocation due to tillage by the ox-drawn ard plough (on average $7 \cdot 8 \mathrm{tha}^{-1} \mathrm{y}^{-1}$ ) appears to be an important source of colluviation behind stone bunds and lynchets in the Ethiopian highlands. The unit soil transport rate $\left(Q_{\mathrm{s}}\right)$ per tillage operation ranges from $4.8 \mathrm{~kg} \mathrm{~m}^{-1}$ on a $0.03 \mathrm{~m} \mathrm{~m}^{-1}$ slope to $38.7 \mathrm{~kg} \mathrm{~m}^{-1}$ on a $0.48 \mathrm{~m} \mathrm{~m}^{-1}$ slope. These values represent the mass of soil deposited by tillage behind one metre of lynchet or stone bund (Nyssen et al., 2000b). Desta et al. (2005) reported tillage erosion rates of the same order of magnitude. 


\section{Creep rates on remobilized debris flows}

Remobilization of debris flows below the Amba Aradam sandstone cliff results in local creep movements over a depth of 1-3 $\mathrm{m}$ at a rate of 3-6 $\mathrm{cm} \mathrm{y}^{-1}$ on slopes of $0.5-0.7 \mathrm{~m} \mathrm{~m}^{-1}$. Palynological evidence from tufa deposited after bedrock became exposed indicates that the reactivation of the flows started some 70 years ago (Nyssen et al., 2002a). Soil shear resistance measurements indicate the risk of continuous or pre-failure creep. From the soil mechanics point of view, the reactivation of the debris flow is due to the combination of two factors: (1) the reduction of flow confining pressures as a result of gully incision and (2) the increase of seepage pressure as a consequence of the cumulative effect of this incision and the increase in infiltration rates on the lobe since grazing and woodcutting were prohibited 8 years before the measurements took place.

\section{Rockfall and rock fragment displacement on cliffs and debris slopes}

Rockfall from cliffs and rock fragment transport on debris slopes under rangeland, mainly by livestock trampling, appear to be important geomorphic processes in the study area. Yearly, along a $1500 \mathrm{~m}$ long section of the Amba Aradam sandstone cliff (Figure 3), at least $80 \mathrm{t}$ of rock fall over a mean vertical distance of $24 \mathrm{~m}$.

Yearly unit rock fragment transport rates on debris slopes are $37.9 \mathrm{~kg} \mathrm{~m}^{-1} \mathrm{y}^{-1}$ in rangeland on basalt (slope gradient $\left.0.55 \mathrm{~m} \mathrm{~m}^{-1}\right)$ and $23.1 \mathrm{~kg} \mathrm{~m}^{-1} \mathrm{y}^{-1}$ in rangeland on sandstone colluvium $\left(0.72 \mathrm{~m} \mathrm{~m}^{-1}\right)$. This process is virtually stopped as a consequence of the establishment of an exclosure: only $3.9 \mathrm{~kg} \mathrm{~m}^{-1} \mathrm{y}^{-1}$ on a $0.85 \mathrm{~m} \mathrm{~m}^{-1}$ slope. The importance of the movement of rock fragments on debris slopes is positively correlated with grazing pressure and areal percentage of smooth surface, and inversely with long grass cover (Nyssen et al., 2006b).

\section{Impacts of soil and water conservation measures}

Effectiveness of stone bunds was measured on runoff plots (Nyssen, 2001) and on stone bunds in farmers' fields (Desta et al., 2005). Though using different approaches, both studies calculated a 'support practice factor' $P$ (as defined in the Revised Universal Soil Loss Equation, Renard et al., 1997) for stone bunds of 0.32 and 0.36-0.39 respectively. These measurements thus show that the introduction of stone bunds on cropland has led to an average reduction in annual soil loss due to water erosion by $61-68 \%$. As the stone bund network was not particularly dense in the catchment, we used the lower value $(61 \%)$ for sediment budgeting.

Sediment deposition rates in exclosures on steep slopes have been measured on similar limestone slopes in the nearby May Ba'ati area using soil profile pits and augerings (Descheemaeker et al., 2006). The area-weighted sediment deposition rate, provided that sufficient eroded sediment from upslope areas enters the exclosure, is $55 \mathrm{tha}^{-1} \mathrm{y}^{-1}$. These sediment trapping areas are generally three to five times smaller than the sediment source area.

The function of trapping sediment by exclosures is, besides their functions of biomass production, biodiversity, carbon sequestration, water storage and runoff decrease, a good reason for the maintenance and extension of this seminatural vegetation on steep slopes (Nyssen et al., 2007c).

\section{Discussion}

\section{Natural versus anthropogenic processes}

Deforestation and the introduction of permanent agriculture were major environmental changes in the study area (Moeyersons et al., 2006), increasing the intensity of most of the erosion processes discussed in this paper. Most processes are the result of an interaction between natural and anthropogenic factors, which we attempted to separate in Table I. The weight of the anthropogenic factor has been determined in a semi-quantitative way, by assessing to which extent the process would be active under natural conditions, i.e. by a comparison of the situation in crop- and rangeland with that in exclosures and under forest.

Whereas rockfall from cliffs is a natural but slow process, individual rock fragment transport over debris slopes is mainly induced by livestock trampling (Table I). The latter process is virtually stopped after establishing exclosures (Nyssen et al., 2006b).

Several studies on gullying in the study area (Brancaccio et al., 1997; Machado et al., 1998; Nyssen et al., 2006c) show that this process can largely be attributed to human-induced environmental changes, resulting in a larger runoff response to rain (Table I), i.e. the removal of shrubs growing in between cultivated land, the decrease of the area covered by dense vegetation, conversions of arable land to overused rangeland and the expansion of bare bedrock 
Table I. Major soil erosion processes in Northern Ethiopia (Dogua Tembien), and the relative impact of natural (black) and anthropogenic (white) factors

\begin{tabular}{|c|c|c|}
\hline Processes & Natural factors ${ }^{\mathrm{a}}$ & Anthropogenic factors \\
\hline Large landslides & $\begin{array}{l}\text { - Steep slopes } \\
\text { - Infiltration } \\
\text { - Extreme events? }\end{array}$ & \\
\hline Rockfall & Presence of cliffs & \\
\hline $\begin{array}{l}\text { Mass movement } \\
\text { reactivation - creep }\end{array}$ & $\begin{array}{l}\text { - Steep slopes } \\
\text { - Clayey colluvium }\end{array}$ & $\begin{array}{l}\text { - Establishment of exclosures } \\
\text { - Slope undercutting by e.g. gully } \\
\text { or road }\end{array}$ \\
\hline Gully erosion & $\begin{array}{l}\text { - Dry spells } \\
\text { - Vertisols in valley } \\
\text { bottoms }\end{array}$ & $\begin{array}{l}\text { - Deforestation } \\
\text { - Removal of remnant vegetation } \\
\text { - Road building } \\
\text { - Eucalypt growing in valley bottom }\end{array}$ \\
\hline Sheet \& rill erosion & $\begin{array}{l}\text { - Steep slopes } \\
\text { - Rain erosivity }\end{array}$ & $\begin{array}{l}\text { - Deforestation } \\
\text { - Removal of remnant vegetation }\end{array}$ \\
\hline Trampling erosion & Steep slopes & Livestock grazing \\
\hline Tillage erosion & & Cultivation of soils \\
\hline
\end{tabular}

${ }^{a}$ Gravity is a natural factor intervening in all processes.

areas, caused by tillage and water erosion. In addition, road building results in rapid gullying below most of the culverts, which is due to increases in catchment area and probably also to a lowering of the topographic threshold values for incipient gullying. Growing eucalyptus trees in valley bottom Vertisols may lead to sizeable drying of the area, including the development of deep cracks, piping, tunnelling and gully development. In addition to human induced environmental changes, the dry years 1978-1989 also had an important impact on gully development rate (Figure 5). It should however be noted that the environment was already more sensitive to soil erosion due to human intervention, magnifying the impact of such environmental fluctuations (Nyssen et al., 2000a, 2002b, 2006c).

Figure 5 represents the medium-term evolution of gully erosion volume in the study area. Such a non-linear increase in gully volume was reported by Graf (1977), Kosov et al. (1978) and Rutherfurd et al. (1997), and is

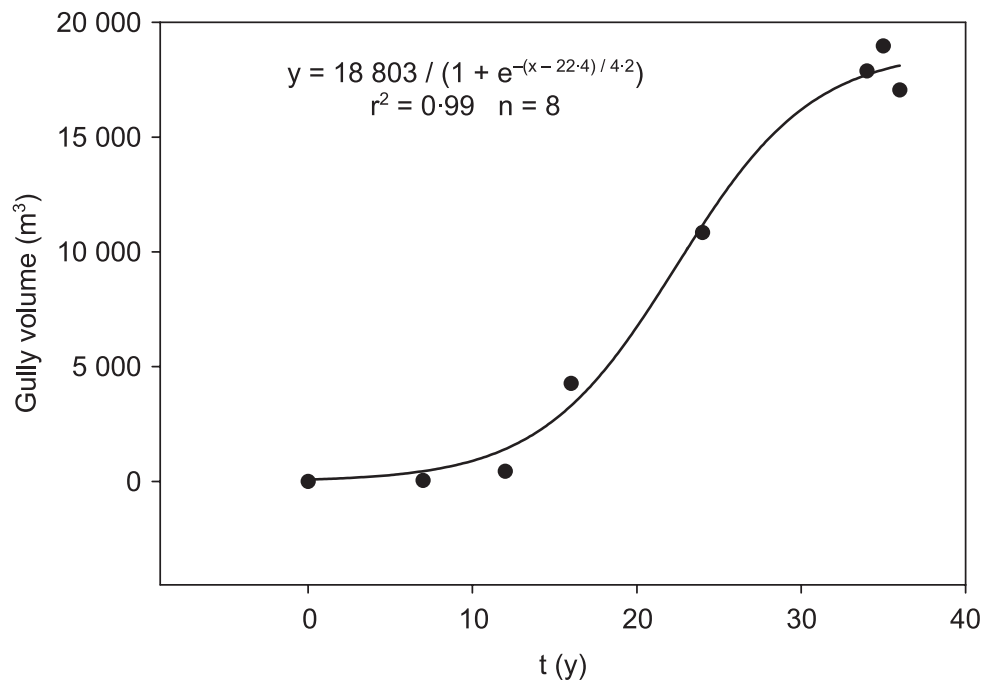

Figure 5. A typical example of the evolution of gully volumes in the study area (after Nyssen et al., 2006c). 


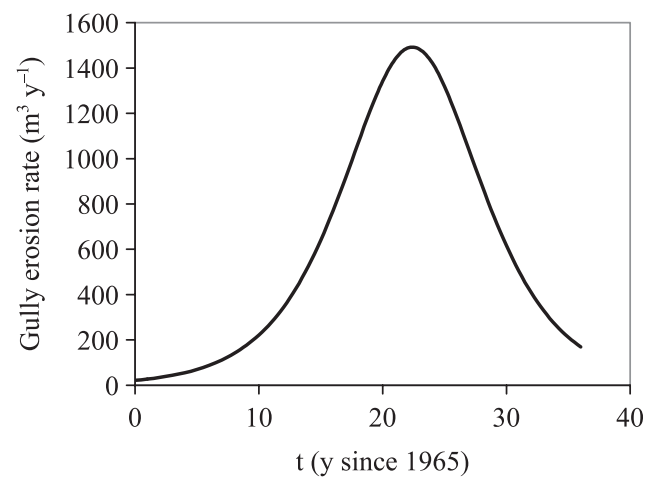

Figure 6. Evolution of gully erosion rates since 1965 - the function is the first derivative of the equation shown in Figure 5.

usually attributed to decreasing catchment area and decreasing stream power (Nachtergaele et al., 2002). In the study area, the decrease of gully volume expansion rate (Figure 5) since around 1995 is attributed to relatively high rainfall (which reduced runoff response due to higher biomass availability and decreased pressure on the land), less interannual rain variability and increased implementation of SWC techniques in the gullies and in the catchment during these years (Nyssen et al., 2006c).

The gully stabilization that was observed in several places in the study area during the fieldwork period 1998-2001 and thereafter, as well as on the curve representing the evolution of gully erosion rate in the study area (Figure 6), is an indicator of the recovery process, induced mainly by the soil and water conservation interventions including exclosure strategy applied within the catchments. Intervention in the gullies itself (check dam building, protection from roaming livestock) enhances this positive evolution.

The medium-term evolution of gully erosion rates was integrated in a set of long-term curves representing schematically the evolution of the intensity of erosion processes since deforestation (Figure 7). Based on our study of the different processes, arrows were added in Figure 7, indicating the direction in which the present-day human impact influences the intensity of the different erosion processes, as discussed below.

Given the continued implementation of stone bund building and the areal increase of exclosures, sheet and rill erosion rates show a trend similar to the one presented in Figure 5. The mean $(n=14$ plot-year data) soil loss rate by sheet and rill erosion on arable land is $9.9 \mathrm{t} \mathrm{ha}^{-1} \mathrm{y}^{-1}$. On the other hand, soil loss by sheet and rill erosion is rather high on rangeland, which is explained by its degraded (overgrazed and compacted) situation. In exclosures, the dense grass cover results in important volumes of trapped sediment. The increasing area of steep slopes under exclosures results in important buffers, reducing runoff and sediment delivery to the river system (Descheemaeker et al., 2006; Nigussie et al., 2005).

With respect to the present-day remobilization of the old mass movements (Figure 7), shear resistance measurements indicate that the steepest part of some debris flows with a matrix of swelling clays, situated in exclosures, might

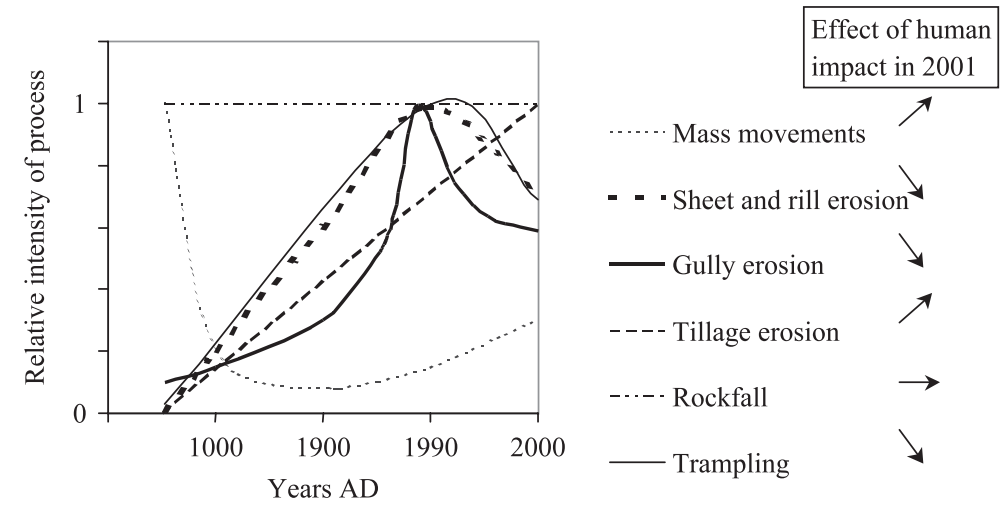

Figure 7. Relative intensity of soil erosion processes since the beginning of deforestation in the Northern Ethiopian Highlands. $0=$ process is not active; I = maximum intensity that has been reached by the process. Note the logarithmic timescale. Arrows on the right indicate for each process whether the current intensity increases, remains constant or decreases as a consequence of human activities, as indicated in Table I. 


\section{Northern Ethiopian Highland soil erosion rate dynamics and controlling factors}

be close to the threshold of failure in the present-day conditions of soil water content and seepage during the second half of the rainy season. The observed creep movement is probably permanent creep, maybe pre-failure creep. This remobilization is thought to be mainly, if not entirely, of anthropogenic origin (Table I). Gully incision, induced by human activities, can explain the reactivation of ancient mass movement deposits, which become disconnected from the stable valley sides by gullying, leading to their mechanical destabilization. Gully incision to a depth below the water table also creates increased seepage pressures. In addition, the exclosure strategy contributes to higher infiltration rates and therefore seepage pressures. Especially ancient mass movement deposits are, during the first years of exclosure, and especially when there is high rainfall, in danger of remobilization (Nyssen et al., 2002a). It must be analysed whether further development of the vegetation might lead to stabilization, as a consequence of (a) drier soils, induced by increased interception of rain and evapotranspiration, and (b) growing roots increasing the internal cohesion (Mulder, 1991; Gyssels et al., 2005). If centuries- or millennia-old deforestation contributed to a slow-down of mass movement activity, present-day human intervention results in a remobilization and dissection of the ancient mass movement deposits. Roadcutting is another trigger of landslides in colluvial material (Nyssen et al., 2002a).

Mean downslope soil flux due to tillage is important, especially on steep slopes, where the ard plough throws all the tilled soil towards the lower side of the furrow. The main triggering factor of this process is soil cultivation (Table I); the main controlling factor is slope gradient. On average, this human-induced process can be held responsible for 25$50 \%$ of the sediment deposited behind stone bunds (Nyssen et al., 2000b; Desta et al., 2005). Tillage erosion intensity continues to increase (Figure 7), probably in an exponential way, given the ongoing expansion of arable land (Nyssen et al., 2007a), especially on steep slopes.

\section{Quantitative assessment of the relative importance of erosion processes}

A sediment budget is an account of the sources and deposition of sediment as it travels from its point of origin to its eventual exit from a drainage basin (Reid and Dunne, 1996). Such a quantitative assessment of the different erosion processes can take into account the lateral component of soil transport, commonly expressed in $\mathrm{tha}^{-1} \mathrm{y}^{-1}$ or in $\mathrm{kg} \mathrm{m}^{-1} \mathrm{y}^{-1}$, or the vertical displacement. Lateral transport is important when considering the land resource, whereas vertical transport and the reduction of the landscape's potential energy are an important concept in long-term landscape evolution (Caine, 1976).

Common units and dimensions are necessary when comparing rates of and volumes affected by different geomorphic processes. Sediment export through the river or gully systems, often averaged over an area, must be made compatible with diffuse translocation (surface creep, tillage erosion, rock fragment movement by trampling), generally expressed as a movement through a unit contour length, and with mass movements, expressed in volume (Caine, 1976). Furthermore, it appears from a literature review on land degradation in the Ethiopian Highlands (Nyssen et al., 2004a) that sediment transfers, which do not reach the drainage system but involve storage, are often either not accounted for, or erroneously included with sediment export through the river system. The measurement units should also allow budgeting these transfers.

Based on 3-7 years erosion monitoring, a horizontal and a vertical sediment budget for the selected catchment have been made. Since no extreme events occurred during the study period, their impact on the sediment budget cannot be foreseen. A zonation of the selected catchment in 'homogenous' land units, based on land use, lithology and slope classes, was carried out (Figure 1).

Soil loss and sediment movement - the horizontal view. Measured and calculated rates of the different geomorphic processes in the study catchment have been summarized in Table II, stating the concerned land units and their projected area. For the 199.1 ha May Zegzeg study catchment, some $72 \%$ (weighted average of $10.7 \mathrm{t} \mathrm{ha}^{-1} \mathrm{y}^{-1}$ ) of total soil loss in 1998-2001 was due to sheet and rill erosion and 28\% (specific rate of $4.7 \mathrm{t} \mathrm{ha}^{-1} \mathrm{y}^{-1}$ ) to gully erosion (Table II). The road in the upper part of the catchment is not providing runoff to the study catchment, but in upland areas influenced by road building, during the first $5 \mathrm{y}$, it is estimated that gully erosion contributes an additional $7.4 \mathrm{tha}^{-1} \mathrm{y}^{-1}$ soil loss. As compared with gullying, a larger part of the total soil loss by sheet and rill erosion is deposited within the catchment (in exclosures and behind stone bunds).

With respect to sediment deposition, the volume of a 6-y-old debris fan reached half of the volume of the upslope gully (Nyssen et al., 2002b). Given the presence of an important debris fan in the upper part of the gully system, we estimated that $30 \%$ (the coarsest part) of soil lost by gully erosion was trapped in debris fans $\left(239 \mathrm{t} \mathrm{y}^{-1}\right)$.

Approximations of sediment deposition in cropland (as a result of the presence of stone bunds) and exclosures were made by Nyssen (2001), Desta et al. (2005), Descheemaeker et al. (2006) and Nyssen et al. (2007c). Based on these field measurements, an average $61 \%$ of the soil eroded from cropland $\left(6 \cdot 0 \mathrm{t} \mathrm{ha}^{-1}\right)$ is estimated to be deposited in plots with stone bunds, which cover approximately half of the cropland in the catchment (Naudts, 2001, unpublished M. 
Table II. Rates of geomorphic processes in the study catchment

\begin{tabular}{|c|c|c|c|c|c|c|}
\hline \multirow[b]{2}{*}{ Process } & \multicolumn{2}{|c|}{ Scale of observation } & \multicolumn{2}{|c|}{ Land unit } & \multirow{2}{*}{$\begin{array}{c}\text { Specific rate } \\
\left(\mathrm{t} \mathrm{ha}^{-1} \mathrm{y}^{-1}\right)\end{array}$} & \multirow{2}{*}{$\begin{array}{c}\text { Total rate } \\
\left(t y^{-1}\right)\end{array}$} \\
\hline & (space) & (time) & name & (ha) & & \\
\hline \multirow[t]{4}{*}{ Sheet \& rill erosion ${ }^{a}$} & plot & $3 y$ & cropland & $133 \cdot 0$ & $9 \cdot 9$ & 1317 \\
\hline & slope & $7 y$ & rangeland & $42 \cdot 3$ & $17 \cdot 4$ & 736 \\
\hline & slope & $7 y$ & exclosures & $21 \cdot 5$ & $3 \cdot 5$ & 75 \\
\hline & & & Subtotal ${ }^{\mathrm{b}}$ & $199 \cdot 1$ & $10 \cdot 7$ & 2128 \\
\hline \multirow[t]{2}{*}{ Gully erosion ${ }^{c}$} & catchment & $3 y$ & catchment & $199 \cdot 1$ & $4 \cdot 1$ & 816 \\
\hline & \multicolumn{3}{|c|}{ Subtotal water erosion } & $199 \cdot 1$ & $14 \cdot 8$ & 2944 \\
\hline
\end{tabular}

Estimated deposition rates of sediment transported by water

\begin{tabular}{|c|c|c|c|c|c|c|}
\hline Exclosures $^{d}$ & study area & $3-15 y$ & exclosures & $21 \cdot 5$ & $55 \cdot 0$ & 1183 \\
\hline $\begin{array}{l}\text { Cropland (behind } \\
\text { SWC structures) }\end{array}$ & \multicolumn{3}{|c|}{ estimated mean ( $61 \%$ of eroded soil) } & $66 \cdot 5$ & $6 \cdot 0$ & 402 \\
\hline Gullies $^{f}$ & \multicolumn{3}{|c|}{ debris fans ( $30 \%$ of eroded soil) } & $199 \cdot 1$ & $1 \cdot 2$ & 239 \\
\hline \multicolumn{5}{|c|}{ Sediment deposition in catchment } & $9 \cdot 2$ & 1823 \\
\hline
\end{tabular}

Other lateral transfers within the catchment

\begin{tabular}{|c|c|c|c|c|c|c|}
\hline Tillage erosiong & within the plot & experim. & all cropland & 133 & $7 \cdot 8$ & 1037 \\
\hline Soil creep ${ }^{i}$ & slope & $2 y$ & steep slopes & $3 \cdot 3$ & $1 \cdot 5$ & 5 \\
\hline Landslides & study area & \multicolumn{5}{|c|}{$\begin{array}{l}\text { - no evidence and not } \\
\text { observed in the catchment during } 4 y\end{array}$} \\
\hline Rockfall $^{j}$ & sandstone cliff & $4 y$ & cliffs & $2 \cdot 3$ & $34 \cdot 7$ & 80 \\
\hline Trampling ${ }^{k}$ & steep slopes & $2 y$ & $\begin{array}{l}\text { - rangeland } \\
\text { - exclosures }\end{array}$ & $\begin{array}{l}42 \cdot 3 \\
21 \cdot 4\end{array}$ & $\begin{array}{l}1 \cdot 3 \\
0 \cdot 1\end{array}$ & $\begin{array}{r}55 \\
3\end{array}$ \\
\hline Sediment yield' & & & Catchment & $199 \cdot 1$ & $5 \cdot 6$ & $|12|$ \\
\hline
\end{tabular}

a Data from Nyssen et al. (2007c), based on mean of monitored rates.

${ }^{b}$ Includes also stone fenced homesteads (zero runoff) and gullies (accounted with gully erosion).

' Data from Nyssen et al. (2006c), based on measurement of gully volumes and estimation of their age.

${ }^{d}$ Based on measurements of sediment accumulation rates in exclosures by Descheemaeker et al. (2006).

${ }^{e}$ According to Nyssen (200I), taking into account that stone bunds are established on half of the cropped area (Naudts, 200 I, unpublished M. Sc. thesis).

${ }^{f}$ Gully volumes were measured taking into account the effect of checkdams - here only deposits in debris fans are taken into account.

${ }^{g}$ Based on Nyssen et al. (2000b), estimation of tillage transport coefficient for the study area $K=68$, two tillage operations (the third, during sowing,

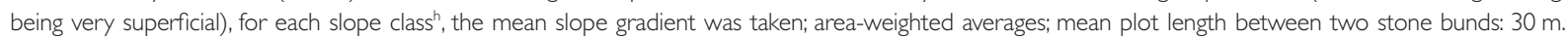

${ }^{\mathrm{h}}$ Flat to sloping, 0-0.15 $\mathrm{m} \mathrm{m}^{-1}$; moderately steep, $0.15-0.30 \mathrm{~m} \mathrm{~m}^{-1}$; steep to extremely steep, $>0.30 \mathrm{~m} \mathrm{~m}^{-1}$ (Van Zuidam, 1986).

' Based on Nyssen et al. (2002a); on basaltic mass movement deposits on steep slopes; mean length: $300 \mathrm{~m}$.

i Data from Nyssen et al. (2006b), mean yearly horizontal displacement $37 \mathrm{~m}$.

${ }^{k}$ Essentially by livestock trampling, but also by concentrated runoff or walking; interpolation based on estimated rock fragment transport coefficient $K$, see Nyssen et al. (2006b); area-weighted means, taking into account lithology and slope gradient class'; mean slope length estimated at $100 \mathrm{~m}$.

'Total water erosion - sediment deposition.

Sc. thesis). In addition to the sediment deposition within cropland $\left(402 \mathrm{t} \mathrm{y}^{-1}\right)$, as well as in debris fans $\left(239 \mathrm{t}^{-1}\right)$, one must also include the deposition in exclosures $\left(55 \mathrm{t} \mathrm{ha}^{-1} \mathrm{y}^{-1}\right.$ or $\left.1183 \mathrm{t} \mathrm{y}^{-1}\right)$. Fifty-five percent of all sediment mobilized by sheet and rill erosion would be trapped in exclosures.

Amongst the diffusion-type processes within the catchment, rockfall $\left(34 \cdot 7 \mathrm{tha}^{-1} \mathrm{y}^{-1}\right)$ and tillage erosion $\left(7 \cdot 8 \mathrm{tha}^{-1} \mathrm{y}^{-1}\right)$ are outstanding. Rockfall however only affects a small area (i.e. the cliffs, $2.3 \mathrm{ha}$ ). The importance of tillage erosion, i.e. the intra-plot redistribution of soil, has increased significantly since the introduction of stone bunds. The effects of this last process have been discussed by Vancampenhout et al. (2006), who found that due to vertical homogeneity within soil profiles (Regosols, Vertisols) tillage erosion does not lead, in most cases, to lateral soil fertility gradients.

Subtracting sediment sinks $\left(1823 \mathrm{t} \mathrm{y}^{-1}\right)$ from catchment sediment sources $\left(2944 \mathrm{t}^{-1}\right)$ results in sediment yield of $1121 \mathrm{t} \mathrm{y}^{-1}$ for a drainage area of $199 \cdot 1 \mathrm{ha}$, or an estimated sediment export rate of $5 \cdot 6 \mathrm{t} \mathrm{ha}^{-1} \mathrm{y}^{-1}$. This is within the range of sediment yields measured in other catchments in the Tigray highlands $\left(1.9-18.2 \mathrm{tha}^{-1} \mathrm{y}^{-1}\right)$, using reservoir sedimentation rates (Nigussie et al., 2007). 


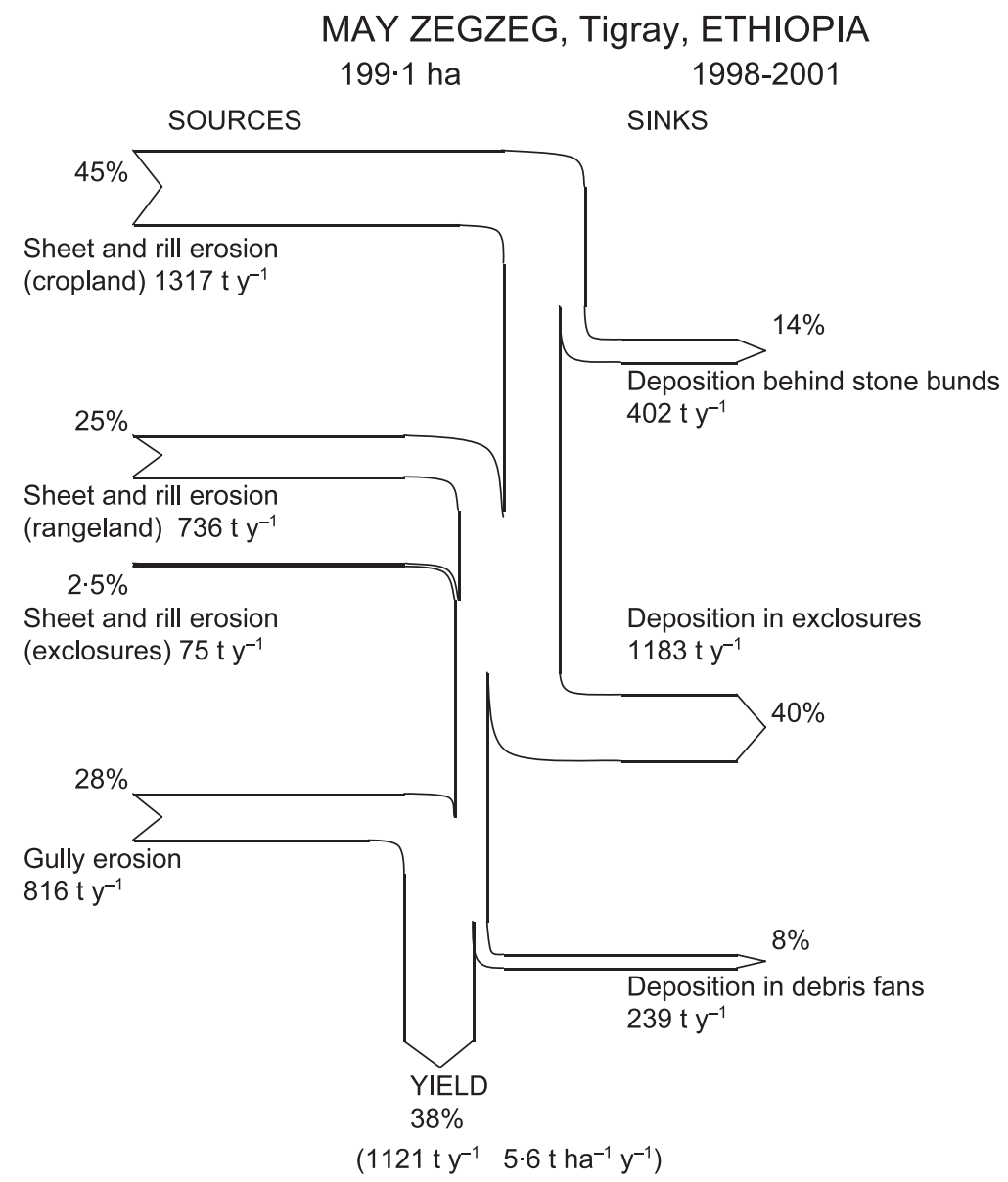

Figure 8. A tentative sediment budget for the study catchment.

The sediment delivery ratio

$$
\mathrm{SDR}=\mathrm{SY} / \mathrm{SL}
$$

where $\mathrm{SY}=$ sediment yield (in $\left.\mathrm{tha}^{-1} \mathrm{y}^{-1}\right)$, and

$$
\mathrm{SL}=\text { soil loss }\left(\text { in } \mathrm{tha}^{-1} \mathrm{y}^{-1}\right)
$$

for the $199 \cdot 1$ ha study catchment is 0.38 (Figure 8 ).

Few sediment budgets have been established for small catchments in semi-arid to subhumid mountainous areas (Table III). Among these catchments, the May Zegzeg had relatively high sediment yield and sediment delivery ratio, which is most probably related to the steep slope gradients.

Reduction of the potential energy of the landscape

Development of a common unit expressing transport rates. Since all - except wind - erosion processes involve transport of soil or parent material from higher to lower elevations, these processes result in a reduction of the potential energy $(E)$ of the landscape, which can be calculated with the equation

$$
\Delta E=m g \Delta z \mathrm{y}^{-1} \quad \text { (after Caine, 1976) }
$$

with $\quad \Delta E=$ change in potential energy $\left(\mathrm{J} \mathrm{y}^{-1}\right)$

$m=$ mass of sediment transported $(\mathrm{kg})$

$g=$ acceleration due to gravity $\left(9 \cdot 81 \mathrm{~kg} \mathrm{~s}^{-2}\right)$

$\Delta z=$ change in elevation of the transported sediment during the considered time period (m). 


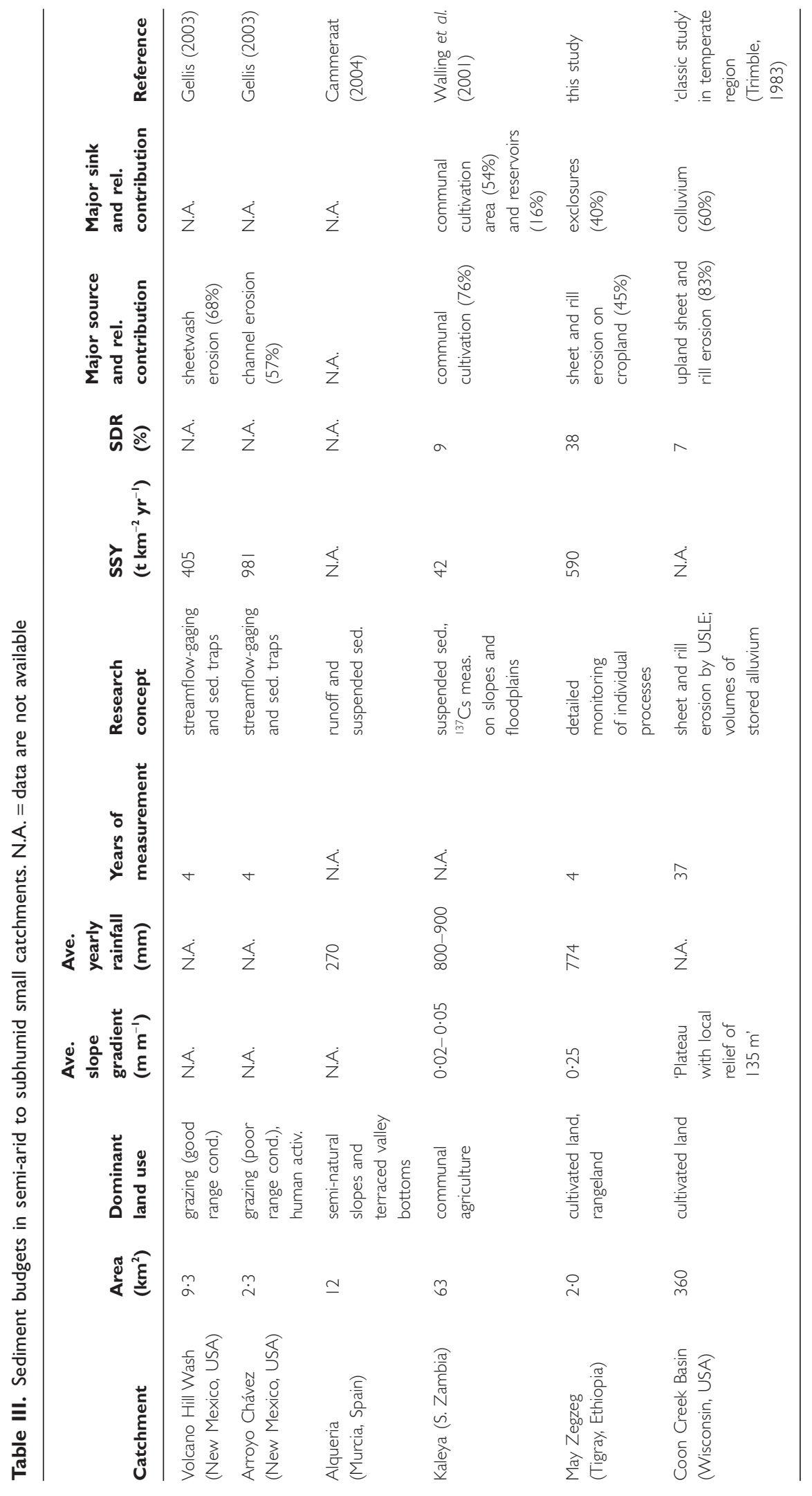




\section{Northern Ethiopian Highland soil erosion rate dynamics and controlling factors}

The use of this equation involves knowledge of the mean elevation of sediment source and deposition area for the different processes. For sediment export through the river system, the catchment outlet will be considered as the elevation of the deposition area (Caine, 1976).

In the case of diffusion-type processes, commonly represented by the equation

$$
Q_{\mathrm{s}}=d D B_{\mathrm{d}} \quad(\text { Kirkby, 1971) }
$$

where $Q_{\mathrm{s}}=$ unit soil transport rate $\left(\mathrm{kg} \mathrm{m}^{-1} \mathrm{y}^{-1}\right)$

$d=$ horizontal component of the mean annual displacement distance $\left(\mathrm{m} \mathrm{y}^{-1}\right)$ of the transported sediment, in the direction of the steepest slope

$D=$ depth of the involved movement (m), measured vertically

$B_{\mathrm{d}}=$ dry soil bulk density $\left(\mathrm{kg} \mathrm{m}^{-3}\right)$,

the distance of movement must be expressed by its vertical component. Hence,

$$
\Delta z=\tan \theta d
$$

where $\theta=$ slope angle

and, for a hypothetical rectilinear slope, without convexities or concavities, either in plan nor in profile,

$$
\Delta E=D A B d g \tan \theta d \mathrm{y}^{-1}
$$

or, using Equation (5),

$$
\Delta E=Q_{\mathrm{s}} A g \tan \theta \mathrm{y}^{-1}
$$

Evidently, the use of Equations (4) and (8) is not only based on the assumption that soil loss measurements have been made for all types of erosion process in the selected catchment, but also on a knowledge of their spatial distribution and of the variability of their intensity, as controlled by slope gradient, land use or other parameters.

Vertical sediment transport in the selected catchment. Using the above-developed Equations (4) and (8), the rates of all the studied erosion processes in terms of change in potential energy $\Delta E$ have been calculated (Table IV). Considering the vertical sediment transport rates, the contribution of gullying in the sediment budget amounts to $28 \%$, because the gullies are located in the lower part of the catchment and hence difference in elevation to the catchment outlet is less. Notably, all diffusion-type processes together account for less than $2 \%$ of the total surface lowering in the catchment, because, if often important masses are displaced by these processes, this occurs only over a short vertical distance. Some 'minor' processes can however be important, either within certain land units (such as creep on ancient mass movement deposits composed of basaltic material), or for the consequences of soil translocation within small areas. Tillage erosion notably leads to soil profile truncation within plots treated with stone bunds, without however leading, in most cases, to the development of lateral soil fertility gradients (Vancampenhout et al., 2006).

Finally, an expression of our results in power $\left(1 \mathrm{~W}=1 \mathrm{~J} \mathrm{~s}^{-1}\right)$ per $\mathrm{km}^{2}$ allows us to compare our data with similar data for other regions of the world (Table V). The magnitude of the different processes is within the range of what was found in other study areas. Unfortunately, no data for tropical mountain areas, or, more generally, for mountain areas transformed by subsistence agriculture, are currently available.

\section{Conclusions}

The anthropogenic factor is determining in the present-day desertification of the Northern Ethiopian Highlands. Human activities (i.e. deforestation, ploughing, livestock grazing, removal of remnant vegetation, road building) led to an overall increase in erosion process intensity, but, through targeted interventions (i.e. stone bund building, establishing check dams in gully channels and exclosures on steep slopes), society is able to control and reverse the degradation processes (Descheemaeker et al., 2006; Nyssen et al., 2006a).

Area-weighted average rate of soil erosion by water in the study catchment was $14.8 \mathrm{tha}^{-1} \mathrm{y}^{-1}$, which accounts for $98 \%$ of the change in potential energy of the landscape. $28 \%$ of total soil loss by water erosion is caused by gully erosion. Other geomorphic processes are also important, either within certain land units, or for their impact on agricultural productivity. Mean sediment deposition rates $\left(9 \cdot 2 \mathrm{tha}^{-1} \mathrm{y}^{-1}\right)$ lead to estimated mean sediment yield rates $\left(5.6 \mathrm{t} \mathrm{ha}^{-1} \mathrm{y}^{-1}\right)$ that are in accordance with sediment yields measured in other small catchments in Tigray. 55\% of total 
Table IV. Change in potential energy, induced by different erosion processes in the study catchment (I99.1 ha)

\begin{tabular}{|c|c|c|c|c|c|c|c|}
\hline \multirow[b]{2}{*}{ Process } & \multicolumn{2}{|c|}{ Land unit } & \multirow{2}{*}{$\begin{array}{l}\text { Mean rate }^{a} \\
\left(\mathrm{t} \mathrm{ha}^{-1} y^{-1}\right)\end{array}$} & \multirow{2}{*}{$\begin{array}{l}\text { Total } \\
\left(t y^{-1}\right)\end{array}$} & \multirow[b]{2}{*}{$\Delta z(\mathrm{~m})$} & \multirow{2}{*}{$\begin{array}{c}\Delta E^{\mathrm{b}} \\
\left(10^{6} \mathrm{~J}^{-1}\right)\end{array}$} & \multirow{2}{*}{$\begin{array}{c}\% \text { of total } \\
\Delta E\end{array}$} \\
\hline & name & (ha) & & & & & \\
\hline \multirow[t]{3}{*}{ Sheet \& rill erosion } & Cropland & $133 \cdot 0$ & $9 \cdot 9$ & 1317 & $130^{c}$ & 1680 & 39 \\
\hline & Rangeland & $42 \cdot 3$ & $17 \cdot 4$ & 736 & $175^{d}$ & 1264 & 29 \\
\hline & Exclosures & $21 \cdot 5$ & $3 \cdot 5$ & 75 & $100^{\mathrm{e}}$ & 74 & 2 \\
\hline Total sheet \& rill erosion & & & & & & 3017 & 70 \\
\hline Gully erosion & & 199 & $4 \cdot 1$ & 816 & $149^{f}$ & 1193 & 28 \\
\hline Subtotal water erosion & & & & & & 4210 & 98 \\
\hline Rockfall & Cliffs & & & 80 & 24 & 19 & $0 \cdot 4$ \\
\hline Diffusion-type processes & & & $Q_{s}\left(k ~ m^{-1} y^{-1}\right)$ & & $\operatorname{Tan} \theta$ & & \\
\hline Tillage erosion & All cropland & 133 & $23 \cdot 4$ & & $0 \cdot 17$ & 52 & $1 \cdot 2$ \\
\hline Soil creepg & Steep slopes & $3 \cdot 3$ & 45 & & $0 \cdot 40$ & 6 & $0 \cdot 1$ \\
\hline \multirow[t]{2}{*}{ Tramplingh } & Rangeland & $42 \cdot 3$ & $13 \cdot 0$ & & $0 \cdot 26$ & 14 & $0 \cdot 3$ \\
\hline & Exclosures & $21 \cdot 4$ & $1 \cdot 4$ & & 0.46 & 1 & 0.02 \\
\hline Total & & & & & & 4302 & 100 \\
\hline
\end{tabular}

a For calculation methods, see Table II.

b Using Equation (4) or (8).

' Estimating a sediment deposition rate of $30 \%$ behind stone bunds within the plot $(\Delta z=1 \mathrm{~m})$ (deposition rate of $61 \%$, on half of the arable land; see Table II), 30\% in exclosures ${ }^{f}(\Delta z=100 \mathrm{~m})$ and $40 \% \operatorname{export}^{\mathrm{f}}(\Delta z=250 \mathrm{~m})$.

Estimating a sediment deposition rate of $50 \%$ in $\operatorname{exclosures}^{f}(\Delta z=100 \mathrm{~m})$ and $50 \%$ export $^{f}(\Delta z=250 \mathrm{~m})$.

${ }^{e}$ Estimating a sediment deposition rate of $50 \%$ in exclosures ${ }^{f}(\Delta z=50 \mathrm{~m})$ and $50 \% \operatorname{export}^{f}(\Delta z=150 \mathrm{~m})$.

${ }^{\mathrm{f}}$ Estimating that $30 \%$ is deposited in debris fans $(\Delta z=30 \mathrm{~m})$ and $70 \%$ leaves the catchment $(\Delta z=200 \mathrm{~m})$.

$\mathrm{g}$ For basaltic mass movement deposits on steep slopes.

${ }^{\mathrm{h}}$ Rock fragment transport, essentially by livestock trampling, but also by concentrated runoff or walking.

Table V. The power of geomorphic work in the study area and in other regions in the world

\begin{tabular}{|c|c|c|c|c|c|c|}
\hline \multirow[b]{3}{*}{ Process } & \multirow{3}{*}{$\begin{array}{c}\Delta E t^{-1} \\
\left(10^{6} \mathrm{Jy}^{-1}\right)\end{array}$} & \multicolumn{5}{|c|}{ Power per unit area $\left(\mathrm{W} \mathrm{km}^{-2}\right)$} \\
\hline & & \multirow{2}{*}{$\begin{array}{c}\text { Study } \\
\text { catchment }\end{array}$} & \multicolumn{4}{|c|}{ Other regions of the world ${ }^{a}$} \\
\hline & & & & minimum & & maximum \\
\hline Sheet \& rill erosion & 3017 & 48 & & & & \\
\hline Gully erosion & 1193 & 19 & & & & \\
\hline Water erosion & 4210 & 67 & $0 \cdot 15^{b}$ & Colorado (Caine, 1976) & $587^{c}$ & Rocky Mts (McPherson, 197I) \\
\hline Rockfall & 19 & $0 \cdot 3$ & $0 \cdot 1$ & Canada (Gardner, 1970) & $0 \cdot 4$ & Scandinavia (Rapp, 1960) \\
\hline Tillage erosion & 52 & $0 \cdot 8$ & & & & \\
\hline Soil creep & 6 & $0 \cdot 1$ & $0 \cdot 11$ & Colorado (Caine, 1976) & $2 \cdot 3$ & Greenland (Washburn, 1967) \\
\hline Trampling $^{d}$ & 15 & $0 \cdot 2$ & & & & \\
\hline Total & 4302 & 69 & & & & \\
\hline
\end{tabular}

${ }^{a}$ Data from Caine (1976).

${ }^{\mathrm{b}}$ Low, because of sediment deposition in catchment lake.

c Measured as suspended load.

${ }^{d}$ Rock fragment transport, essentially by livestock trampling, but also by concentrated runoff or walking.

soil loss by sheet and rill erosion is trapped more downslope in exclosures, whereas, in cropland with stone bunds, $61 \%$ of the eroded soil mass is already deposited, behind the bunds.

With respect to the relative importance of soil loss rates by sheet and rill erosion vs. gully erosion, not only is sheet and rill erosion more important when expressed in $\mathrm{tha}^{-1}$ ( $72 \%$ versus $28 \%$ for gully erosion) but such is also the case when the vertical transport, which takes into account the important deposition rate of sediment mobilized by sheet and rill erosion, is considered. The importance of gullying should however not be underestimated: first, gully channels 


\section{Northern Ethiopian Highland soil erosion rate dynamics and controlling factors}

are important pathways for the export of sediment produced by sheet and rill erosion and as such they increase the sediment connectivity in landscapes (Poesen et al. 2003), and second, the topographic deformations caused by gullying result in important, immediate agricultural production losses. Hence, gully erosion calls for remedial action: in the study area, soil conservation works are carried out both in the gullies and in their drainage areas, resulting in a decrease of short-term gully erosion rates to approximately $10 \%$ of sheet and rill erosion rates (Nyssen et al., 2006c).

\section{Acknowledgements}

This study was made in the framework of research programme G006598.N funded by the Fund for Scientific Research - Flanders, Belgium, and of the Zala-Daget project (VLIR-EI, Belgium). Thanks go to Berhanu Gebremedhin Abay for assistance with all the fieldwork. Numerous farmers agreed to share their knowledge with us. The local Agricultural Office, REST (Relief Society of Tigray) branch, the May Zegzeg Integrated Watershed Management Project office and the authorities of the concerned villages and district facilitated the research. Scientific and technical personnel of the Physical and Regional Geography Research Group, K.U. Leuven, supported the research in various ways.

\section{References}

Abu-Zreig M. 2001. Factors affecting sediment trapping in vegetated filter strips simulation study using VFSMOD. Hydrological Processes 15: $1477-1488$.

Arkin Y, Beyth M, Dow DB, Levitte D, Temesgen Haile, Tsegaye Hailu. 1971. Geological Map of Mekele Sheet Area ND 37-11, Tigre Province, 1:250·000, Imperial Ethiopian Government, Ministry of Mines, Geological Survey: Addis Ababa.

Brancaccio L, Calderoni G, Coltorti M, Dramis F. 1997. Phases of soil erosion during the Holocene in the Highlands of Western Tigray (Northern Ethiopia): a preliminary report. In The Environmental History and Human Ecology of Northern Ethiopia in the Late Holocene, Bard K (ed.). Istituto Universitario Orientale: Napoli; 30- 48.

Caine C. 1976. A uniform measure of subaerial erosion. Geological Society of America Bulletin 87(1): 137-140.

Cammeraat E. 2004. Scale dependent thresholds in hydrological and erosion response of a semi-arid catchment in southeast Spain. Agriculture, Ecosystems and Environment 104: 317-332.

Descheemaeker K, Nyssen J, Rossi J, Poesen J, Mitiku Haile, Moeyersons J, Deckers J. 2006. Sediment deposition and pedogenesis in exclosures in the Tigray Highlands, Ethiopia. Geoderma 132: 291-314.

Desta Gebremichael, Nyssen J, Poesen J, Deckers J, Mitiku Haile, Govers G, Moeyersons J. 2005. Effectiveness of stone bunds in controlling soil erosion on cropland in the Tigray highlands, Northern Ethiopia. Soil Use and Management 21(3): $287-297$.

Gardner J. 1970. Rockfall: a geomorphic process in high mountain terrain. Albertan Geographer 6: 15-20.

Garzanti E, Andò S, Vezzosi G, Abdel Megid AA, El Kammar A. 2006. Petrology of Nile River sands (Ethiopia and Sudan): sediment budgets and erosion patterns. Earth and Planetary Science Letters 252: 327-341.

Gellis A. 2003. Sediment budgets for two semi-arid watersheds, Rio Puerco basin, New Mexico. Poster presented at XVI INQUA Congress, Reno, USA. http://gsa.confex.com/gsa/inqu/finalprogram/session_3443.htm. Accessed on 23 July 2007.

Graf W. 1977. The rate law in fluvial geomorphology. American Journal of Science 27: 178-191.

Gyssels G, Poesen J, Bochet E, Li Y. 2005. Impact of plant roots on the resistance of soils to erosion by water: a review. Progress in Physical Geography 29(2): 189-217.

Herweg K, Ludi E. 1999. The performance of selected soil and water conservation measures - case studies from Ethiopia and Eritrea. Catena 36: 99-114.

Hurni H. 1985. Erosion-productivity-conservation systems in Ethiopia. Proceedings 4th International Conference on Soil Conservation, Maracay, Venezuela; 654-674.

Hurni H. 1990. Degradation and conservation of soil resources in the Ethiopian Highlands. Mountain Research and Development 8(2/3): $123-130$.

Hutchinson RW, Engels GG. 1970. Tectonic significance of regional geology and evaporite lithofacies in northeastern Ethiopia. Philosophical Transactions of the Royal Society of London. A. Mathematical and Physical Sciences 267: 313-330.

Kirkby M. 1971. Hillslope process-response models based on the continuity equation. Institute of British Geographers Special Publication 3: 331-344.

Kosov B, Nikolskaya I, Zorina Y. 1978. Experimental research on gully formation. In Experimental Geomorphology Vol. 3, Makkaveev N (ed.). Moscow University Press: Moscow; 113-140 (in Russian).

Lacey ST. 2000. Runoff and sediment attenuation by undisturbed and lightly disturbed forest buffers. Water, Air and Soil Pollution 122: 121-138.

Luk S, Abrahams AD, Parsons AJ. 1993. Sediment sources and sediment transport by rill flow and interrill flow on a semi-arid piedmont slope, Southern Arizona. Catena 20: 93-111.

Machado MJ, Perez-Gonzalez A, Benito G. 1998. Paleoenvironmental changes during the last 4000 yr in Tigray, Northern Ethiopia. Quaternary Research 49: 312-321.

McPherson H. 1971. Dissolved, suspended and bed load movement patterns in Two O'Clock Creek, Rocky Mountains, Canada, summer 1969. Journal of Hydrology 12: 221-233. 


\section{J. Nyssen et al.}

Merla G. 1938. I depositi intervulcanici. In Missione Geologica nel Tigrai, Merla G, Minucci E (eds). Reale Accademia d'Italia: Rome; 332-336.

Merla G, Abbate E, Azzaroli A, Bruni P, Canuti P, Fazzuoli M, Sagri M, Tacconi P. 1979. A Geological Map of Ethiopia and Somalia (1973) 1:2.000.000 and Comment. University of Florence: Florence.

Moeyersons J, Nyssen J, Poesen J, Deckers J, Mitiku Haile. 2006. Age and backfill/overfill stratigraphy of two tufa dams, Tigray Highlands, Ethiopia: evidence for Late Pleistocene and Holocene wet conditions. Palaeogeography, Palaeoclimatology, Palaeoecology 230(1/2): $162-178$.

Mulder H. 1991. Assessment of Landslide Hazard, Ph.D. thesis, Faculty of Geographical Sciences, University of Utrecht.

Nachtergaele J, Poesen J, Oostwoud Wijdenes D, Vandekerckhove L. 2002. Medium-term evolution of a gully developed in a loess-derived soil. Geomorphology 46(3/4): 223-239.

Nigussie Haregeweyn, Poesen J, Deckers J, Nyssen J, Mitiku Haile, Govers G, Verstraeten G, Moeyersons J. 2007. Sediment-bound nutrient export from micro-dam catchments in Tigray. Land Degradation and Development in press.

Nigussie Haregeweyn, Poesen J, Nyssen J, Verstraeten G, de Vente J, Govers G, Deckers J, Moeyersons J. 2005. Specific sediment yield in Tigray - Northern Ethiopia: assessment and semi-quantitative modelling. Geomorphology 69: 315-331.

Nyssen J. 2001. Erosion Processes and Soil Conservation in a Tropical Mountain Catchment under Threat of Anthropogenic Desertification - a Case Study from Northern Ethiopia, Ph.D. thesis, K.U. Leuven, Belgium.

Nyssen J, Mitiku Haile, Poesen J, Deckers J, Moeyersons J. 2001. Removal of rock fragments and its effect on soil loss and crop yield, Tigray, Ethiopia. Soil Use and Management 17: 179-187.

Nyssen J, Moeyersons J, Deckers J, Mitiku Haile, Poesen J. 2000a. Vertic movements and the developments of stone covers and gullies, Tigray Highlands, Ethiopia. Zeitschrift für Geomorphologie N.F. 44(2): 145-164.

Nyssen J, Moeyersons J, Poesen J, Deckers J, Mitiku Haile. 2002a. The environmental significance of the remobilisation of ancient mass movements in the Atbara-Tekeze headwaters, Northern Ethiopia. Geomorphology 49: 303-322.

Nyssen J, Naudts J, De Geyndt K, Deckers J, Mitiku Haile, Poesen J, Moeyersons J. 2007a. Soils and land use in the Tigray Highlands (Northern Ethiopia). Soil Use and Management in press.

Nyssen J, Poesen J, Deckers J, Desta Gebremichael, Vancampenhout K, D’aes M, Gebremedhin Yihdego, Govers G, Mitiku Haile, Moeyersons J, Naudts J, Nigussie Haregeweyn. 2006a. On-site evaluation of stone bunds to control soil erosion on cropland in Northern Ethiopia. Soil and Tillage Research 94: 151-163.

Nyssen J, Poesen J, Descheemaeker K, Nigussie Haregeweyn, Mitiku Haile, Moeyersons J, Govers G, Munro RN, Deckers J. 2007b. Reversing land degradation in marginal semi-arid areas: the case of Northern Ethiopia. Ecosystems submitted.

Nyssen J, Poesen J, Mitiku Haile, Moeyersons J, Deckers J. 2000b. Tillage erosion on slopes with soil conservation structures in the Ethiopian highlands. Soil and Tillage Research 57(3): 115-127.

Nyssen J, Poesen J, Mitiku Haile, Moeyersons J, Deckers J, Hurni H. 2007c. Effect of land use and land cover on sheet and rill erosion rates in the Tigray Highlands, Ethiopia. Soil and Tillage Research submitted.

Nyssen J, Poesen J, Moeyersons J, Deckers J, Lavrysen E, Mitiku Haile. 2006b. Processes and rates of rock fragment displacement on cliffs and scree slopes in an amba landscape, Ethiopia. Geomorphology 81: 265-275.

Nyssen J, Poesen J, Moeyersons J, Deckers J, Mitiku Haile, Lang A. 2004a. Human impact on the environment in the Ethiopian and Eritrean Highlands - a state of the art. Earth Science Reviews 64(3/4): 273-320.

Nyssen J, Poesen J, Moeyersons J, Luyten E, Veyret-Picot M, Deckers J, Mitiku Haile, Govers G. 2002b. Impact of road building on gully erosion risk: a case study from the northern Ethiopian Highlands. Earth Surface Processes and Landforms 27: 1267-1283.

Nyssen J, Poesen J, Veyret-Picot M, Moeyersons J, Mitiku Haile, Deckers J, Dewit J, Naudts J, Kassa Teka, Govers G. 2006c. Assessment of gully erosion rates through interviews and measurements: a case study from Northern Ethiopia. Earth Surface Processes and Landforms 31(2): 167-185.

Nyssen J, Vandenreyken H, Poesen J, Moeyersons J, Deckers J, Mitiku Haile, Salles C, Govers G. 2005. Rainfall erosivity and variability in the Northern Ethiopian Highlands. Journal of Hydrology 311: 172-187.

Nyssen J, Veyret-Picot M, Poesen J, Moeyersons J, Mitiku Haile, Deckers J, Govers G. 2004b. The effectiveness of loose rock check dams for gully control in Tigray, Northern Ethiopia. Soil Use and Management 20: 55-64.

Poesen J, Nachtergaele J, Verstraeten G, Valentin C. 2003. Gully erosion and environmental change: importance and research needs. Catena 50(2-4): 91-133.

Rapp A. 1960. Recent developments of mountain slopes in Karkevagge and surroundings, northern Scandinavia. Georgrafiska Annaler 42: 71-200.

Reid L, Dunne T. 1996. Rapid Evaluation of Sediment Budgets. Catena GeoEcology: Reiskirchen.

Renard KG, Foster GR, Weesies GA, McCool DK, Yoder DC (coordinators). 1997. Predicting Soil Erosion by Water: a Guide to Conservation Planning with the Revised Universal Soil Loss Equation (RUSLE), Agriculture Handbook 703. United States Department of Agriculture: Washington, DC.

Rey F. 2003. Influence of vegetation distribution on sediment yield in forested marly gullies. Catena 50: 549-562.

Rutherfurd ID, Prosser IP, Davis J. 1997. Simple approaches to predicting rates and extent of gully development. In Proceedings of the Conference on Management of Landscapes Disturbed by Channel Incision, Wang SSY, Langendoen EJ, Shields FD (eds). Center for Computational Hydroscience and Engineering, University of Mississippi: USA; 1125-1130.

Slaymaker O. 2003. The sediment budget as conceptual framework and management tool. Hydrobiologia 494: 71-82.

Solomon Gebregziabher, Mouazen A, Van Brussel H, Ramon H, Nyssen J, Verplancke H, Mintesinot Behailu, Deckers J, De Baerdemaeker J. 2006. Animal drawn tillage, the Ethiopian ard plough - Maresha: a review. Soil and Tillage Research 89: 129-143.

Ståhl M. 1974. Ethiopia: Political Contradictions in Agricultural Development. Rabén \& Sjögren, Stockholm. 


\section{Northern Ethiopian Highland soil erosion rate dynamics and controlling factors}

Ståhl M. 1990. Environmental degradation and political constraints in Ethiopia. Disasters. The Journal of Disaster Studies and Management 14: $140-150$

Sutcliffe JV, Parks YP. 1999. The Hydrology of the Nile, International Association of Hydrological Sciences (IAHS) Special Publication 5. IAHS: Wallingford, Oxfordshire.

Syvitski J, Milliman J. 2007. Geology, geography, and humans battle for dominance over the delivery of fluvial sediment to the coastal ocean. Journal of Geology 115: 1-19.

Trimble SW. 1983. A sediment budget for Coon Creek basin in the Driftless area, Wisconsin, 1853-1977. American Journal of Science 283: 454-474.

Vancampenhout K, Nyssen J, Desta Gebremichael, Deckers J, Poesen J, Mitiku Haile, Moeyersons J. 2006. Stone bunds for soil conservation in the northern Ethiopian highlands: impacts on soil fertility and crop yield. Soil and Tillage Research 90: 1-15.

Van Zuidam R. 1986. Aerial Photo-Interpretation in Terrain. Analysis and Geomorphological Mapping. Smits: The Hague.

Walling DE, Collins AL, Sichingabula HM, Leeks G. 2001. Integrated assessment of catchment suspended sediment budgets: a Zambian example. Land Degradation and Development 12: 387-415.

Washburn A. 1967. Instrumental observations of mass-wasting in the Mesters Vig district, northeast Greenland. Meddelelser om Grønland 166(4).

Westphal E. 1975. Agricultural Systems in Ethiopia. Centre for Agricultural Publishing and Documentation: Wageningen.

Wilkinson B. 2005. Humans as geologic agents: a deep-time perspective. Geology 33: 161-164. 